\title{
Synthesis of Anisole Derivatives from 4-Alkylidene-2-cyclohexen-1-ones with Iodine in Methanol
}

\author{
Jeong Mi Kim, Ka Young Lee, Taek Hyeon Kim," and Jae Nyoung Kim \\ Deparment of Chemistry and Institute of Basic Science, Chomam National Lniversitv, Gwangh 500-757, Korea \\ Faculy of Applied Chemistry, Chonham National Lniversity, Gwangiu 500-757, Korea \\ Received March 28, 2003
}

Key Words : Anisoles. 4-Alkylidene-2-cyclohexen-1-ones, Iodine, Methanol, Baylis-Hillman acetates

Chaniakh and Anri have reported the synthesis of 4 alhylidene-2-cyclohexen-1-ones from the reaction of BaylisHillnan acetates and b-diketones in ethanol in the presence of $\mathrm{K}_{2} \mathrm{CO}_{3}$ (Scheme 1). ${ }^{3}$ Recently: we have reported the facile synthesis of ortho-hydroxyacetophenones from the same reaction in DMF (Scheme 1). ${ }^{2}$ Besides ontho-hydroxyacetophenones, we are recently interested in the synthesis of aronatic and heteroaromatic compounds from Baylis-Hilman adducts, which included quinolines or naphthalenes. ${ }^{3}$ In these respects, we exanimed the possibility of converting 4alhylidene-2-cyclohexen-1-ones 1 to the corresponding arontatic conpounds such as anisole or phenol derivatives. Suitably substituted phenol or anisole derivatives are useful as starting materials for the preparation of fragrances. dyes and pesticides. as antioxidants in oils and fats or as stabilizers of plastics. ${ }^{+}$

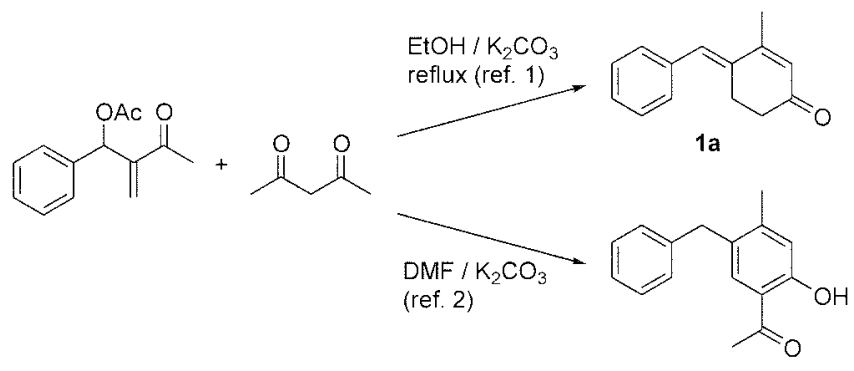

Scheme 1

Kotnis reported the aromatization of a wide variety of Hagemann's esters by heating with iodine and methanol to $p$-nethoxybenzoates. ${ }^{\text {sa }}$ It has also been reported that cyclohexenone can be aronatized with iodine, cerium anumonium nitrate in various alcohols. ${ }^{\text {sb }}$ Originally, Tanura and Yoshimoto have reported the synthesis of anisole derivatives by aromatization of cyclohexeneones using iodine and methanol.t. Such a novel aromatization method has been used for the synthesis of natural products, successfully. ${ }^{6}$ Hegde and coworkers have reported the aromatization of 2-cyclohexenone-4-carboxylates with iodine and sodium ethoxide to 2 iodophenoles. ${ }^{i}$ Iodine-methanol system can be used for the aromatization of 1.4-dihydropyridines into pyridines ${ }^{8 / 4}$ and tetralyydro-4-quinolones into 2-aryl-4-methosy quinolines. ${ }^{8 \mathrm{~b}}$ Recently, iodine-methanol induced fragmentation of bicyclic diones has been reported." These reports confirmed the feasibility for the synthesis of anisole derivatives from 4 alkylidene-2-cyclohexen-1-ones (Scheme 2). Exo-methy lene moiety in the starting materials night have the key for the successful reaction. We thought that the initial conjugate addition of methanol could be possible to produce the intermediate $\mathbf{I}$, which could undergo the next aromatization reaction according to the reported process.

As expected. anisole derivative 2 a was obtained in $64 \%$

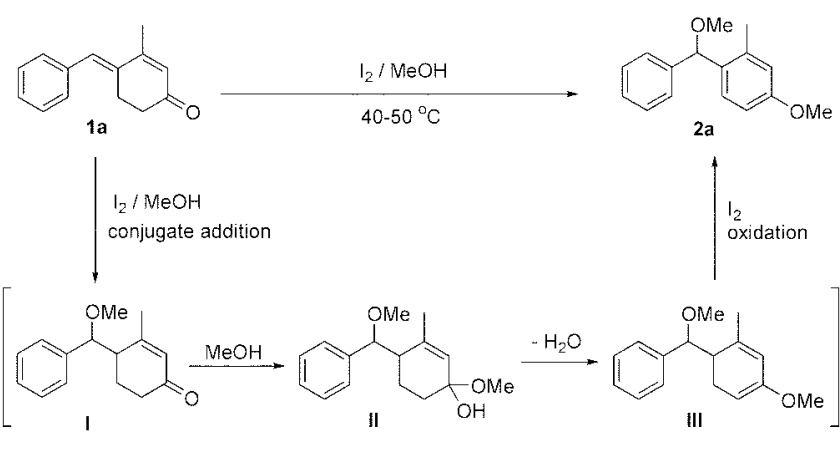

Scheme 2

isolated yield from the reaction of $1 \mathrm{a}$ and iodine ( 1.1 equiv) in methanol at $40-50^{\circ} \mathrm{C}$ (Scheme 2). As shown in Scheme 2, the mechanism could be thought as follows. (1) Conjugate

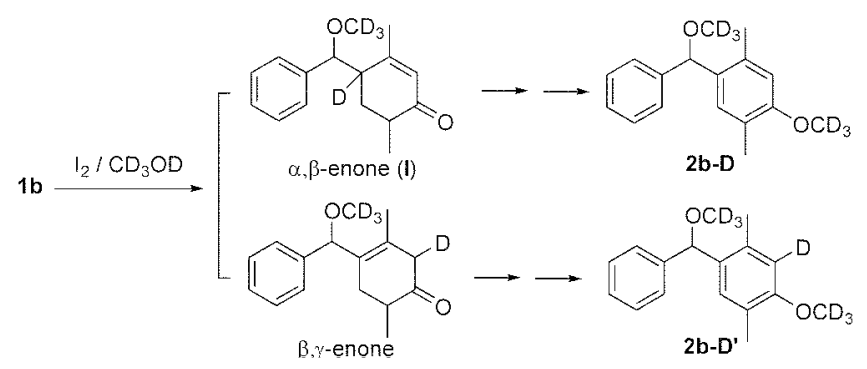

Figure 1 
Table 1. Sinthesis of anisoles with iodine/MeOH

(1)

addition of methanol to 1a to give I (vide infra. Figure 1). ${ }^{\text {ji }}$ (2) Formation of hemiketal II followed by dehydration into III. ${ }^{\text {\&b }}$ (3) Iodine catalyzed oxidation of III to give the desired product $2 \mathrm{a}^{\mathrm{z}_{\mathrm{a}}}$ The reaction of $\mathbf{1 b}$ with iodine in deuterated methanol, $\mathrm{CD}_{3} \mathrm{OD}$. afforded $2 \mathrm{~b}-\mathrm{D}$ in $32 \%$ isolated yield (entry 3 in Table 1). ${ }^{11}$ The other plausible product $\mathbf{2 b}$-D' with deuterium at the 2-position of anisole moiety was not observed. from which we proposed the first step as the conjugate addition to generate $\alpha \beta$-enone derivative (Figure

Table 2. Some other results from the reaction of $1 b$

entry conditions

1) ${ }^{10.1]}$ Similar results were observed with various 4-alkylidene-2-cyclohexen-1-ones $\mathbf{1 b - g}$. Representative results are summarized in Table 1. Starting materials, 4-alkylidene-2cyclohexen-l-ones $1 \mathbf{a}-\mathrm{g}$. were prepared according to the Amri"s procedure from the reaction of Baylis-Hillman acetates and $\beta$-diketones in ethanol in the presence of $\mathrm{K}_{2} \mathrm{CO}_{3}$.

The reaction of $\mathbf{1 b}$ and iodine in other alcohol solvents such as ethanol or $n$-propanol gave the corresponding aromatized compounds $\mathbf{2 h}$ and $\mathbf{2 i}$ in moderate yields. When the reaction was performed at elevated temperature (entry 2 in Table 2) unusual compound such as $\mathbf{2 h}$ " was isolated. ${ }^{12}$ Experimental procedure and spectroscopic data of some of the synthesized compounds are summarized in experimental section.

In summary, we applied the well-known iodine-methanol system for the synthesis of highly substituted anisole derivatives. The results extended the useful aromatization method to the cyclohexenone system containing exocyclic double bond for the first time. Studies on the mechanism for the formation of some unusual compounds including $2 \mathrm{f}^{\prime}$, $\mathbf{2 g ^ { \prime }}$. $2 \mathbf{h}^{\prime}$ and $\mathbf{2} \mathrm{h}^{\prime \prime}$ and the study for the synthesis of phenolic compounds selectively are underway.

\section{Experimental Section}

Typical procedure: A stirred solution of 1a (198 mg. 1.0 mmol) and iodine (280 mg. $1.1 \mathrm{mmol})$ in methanol $(3 \mathrm{~mL})$ was gently heated to $40-50^{\circ} \mathrm{C}$ for $7 \mathrm{~h}$. The reaction mixture was poured into cold water and extracted with ether. The organic phase was washed successively with $\mathrm{NaHSO}_{3}$ solution and brine. After removal of solvent and following column chromatographic purification (hexane/ether. $50: 1$ ) desired 2a was obtained as an oil, $155 \mathrm{mg}(64 \%)$. Spectroscopic data of $2 \mathrm{a}$ was as follows. ${ }^{1} \mathrm{H}$ NMR $\left(\mathrm{CDCl}_{3}\right) \delta 2.26(\mathrm{~s}, 3 \mathrm{H}), 3.36$ (s, 3H), 3.77 (s. 3H). 5.36 (s, lH), 6.69-6.75 (m, 2H), 7.22$7.32(\mathrm{~m}, 6 \mathrm{H}):{ }^{13} \mathrm{C} \mathrm{NMR}\left(\mathrm{CDCl}_{3}\right) \delta 19.55 .55 .11 .56 .91 .82 .33$. $110.91,116.18,127.28 .127 .31 .128 .24,128.38,131.96$, 137.59. 141.37. 158.78: Mass (70 eV) $\mathrm{mz}$ (rel intensity) 77 (14). 105 (17). 149 (17). 165 (87). 211 (100). $242\left(\mathrm{M}^{+} .45\right)$.

Selected spectroscopic data of $\mathbf{2 b - D}$. $2 \mathrm{f}^{\prime}$ and $\mathbf{2} \mathbf{h}^{\prime \prime}$ are as follows.

2b-D: white solid: mp 67-68 ${ }^{\circ} \mathrm{C}:{ }^{~} \mathrm{H}$ NMR $\left(\mathrm{CDCl}_{3}\right) \delta 2.17$ (s. $3 \mathrm{H}$ ). 2.26 (s. $3 \mathrm{H}$ ). 5.36 (s. 1H). 6.59 (s. 1H). 7.12 (s. $1 \mathrm{H}$ ). 7.22-7.31 (m, 5H): ${ }^{13} \mathrm{C}$ NMR (125 MHz, $\left.\mathrm{CDCl}_{2}\right) \delta 15.89$. 19.40. 54.44 (septet. $J_{C \cdot D}=21.5 \mathrm{~Hz}$ ). 56.06 (septet. $J_{C \cdot D}=$ $21.5 \mathrm{~Hz}) .82 .07,112.10 .123 .80 .127 .17,127.20,128.23$. $129.33,131.12,134.37,141.62,156.74$.

2f': oil: ' $\mathrm{H}$ NMR $\left(\mathrm{CDCl}_{3}\right) \delta 1.69(\mathrm{~d}, J=0.9 \mathrm{~Hz}, 3 \mathrm{H}), 1.88$ (d. $J=0.9 \mathrm{~Hz}, 3 \mathrm{H}$ ). 2.17 (s. $3 \mathrm{H}$ ), 2.20 (s. $3 \mathrm{H}$ ). 3.81 (s. $3 \mathrm{H}$ ). 6.13 (br s. $1 \mathrm{H}$ ). 6.64 (s. $1 \mathrm{H}) .6 .89$ (s. $1 \mathrm{H}):{ }^{13} \mathrm{C}$ NMR $\left(\mathrm{CDCl}_{3}\right)$ $\delta 15.73,19.23,19.92,26.02,55.29,111.48 .122 .96 .123 .64$. $129.81,131.66,134.06,134.65 .155 .94$.

2h": white solid: $\operatorname{mp} 219-220^{\circ} \mathrm{C}$ (lit. ${ }^{12} 229-230^{\circ} \mathrm{C}$ ): IR (KBr) $3344 \mathrm{~cm}^{-1}$ : ${ }^{1} \mathrm{H}$ NMR (CDCl $\left.\mathrm{l}_{2}+\mathrm{DMSO}-\mathrm{d}_{6}\right) \delta 2.04$ (s. $6 \mathrm{H}$ ). 2.07 (s. $6 \mathrm{H}$ ). 5.45 (s. 1H). 6.42 (s. 2H). 6.62 (s. $2 \mathrm{H}$ ). $7.00-7.31$ (m. $5 \mathrm{H}$ ). 7.39 (s. $\mathrm{D}_{2} \mathrm{O}$ exchangeable. $2 \mathrm{H}$ ): ${ }^{13} \mathrm{C}$ NMR $\left(\mathrm{CDCl}_{3}+\text { DMSO-d }\right)^{\prime} \delta 15.84,19.19,49.00,116.92$. 
$120.80,125.71,128.01 .129 .69,131.58,133.48,134.72$. 144.08, 152.81; Mass (70 eV) $m z$ (rel intensity) 195 (42). 209 (27). 255 (36). $317(100), 332\left(\mathrm{M}^{+} .89\right)$.

Acknowledgments. This work was supported by the Korea Research Foundation Grant (KRF-2002-015-CP0215). The support of the Korea Basic Science Institute (Kwangju branch) is also acknowledged

\section{References and Notes}

1. Chamakh. A.: Amri. H. Tetrohedron Lett. 1998. 39. 375.

2. Kim. J. N.: Im. Y. J.: Kim. J. M. Tetrohedron Lett. 2002 . 13. 6597.

3. (a) Lee, K. Y: Kim. I. M: Kim, I. N. Tetahedron 2003. 59.385. (b) Kim. I. N.: Chung. Y. M. In1. Y. J. Tetraheatron Lett. 2002. 43, 6209. (c) In. Y. I.: Lee. K. Y.: Kim. T. H.: Kim. J. N. Tetrahedtront Lett. 2002. 13. 4675. (d) Kim. J. N.: Lee. H. J.: Lee. K. Y.: Kim. H. S. Tetrahedron Lett. 2001. 42. 3737. (e) Kim. J. N.: Im. Y. J.: Gong. J. H.: Lee. K. Y. Tetrahedron Lett. 2001. 42. 4195. (f) Kim. I. N.: Kim. H. S.: Gong. I. H.: Chung. Y. M. Tetrahedron Lett. 2001, 22,8341. (g) Kim, J. N.: Lee. K. Y.: Kim, H. S: Kim. T. Y. Org. Lett. $2000,2,343$. (h) Kim. J. N.: Lee. K. Y. Curr. Org. Chem. 2002. 6. 627, and further references cited therein.

4. Dorothea. G. Phenol derivatives. Cllmams Encyclopedia of
Industrial Chentistry, Barbara, E.; Stephen, H.: Gail. S.. Eds. VCH: Weinheim. 1991: Vol. A19.

5. (a) Kottis. A. S. Tetrohe dron Lett. 1990. 31. 481. (b) Horiuchi. C A.: Fulunishi. H.: Kajita. M.: Yamaguchi. A.: Kiyomiya. H.: Kiji. S. Chem Lett 1991. 1921. (c) Tamura. Y.: Yoshimoto, Y. Chem. Ind. 1980,888 .

6. (a) Schoop. A.: Greiving, H.: Gohrt. A. Tetmahedron Lett. 2000 H. 1913. (b) Kotnis. A. S. Tetrahedon Lett. 1991. 32. 3441.

7. Hegde. S. G.: Kassim. A. M.: Ingrum. A. I. Tetrahedron Lett. 1995. 36. 8395 .

8. (a) Yadav, J. S.; Reddy, B. V. S.: Sabitha. G.; Reddy, G. S. K. K. Synthesis 2000, 1532. (b) Mphahlele, M. J.: Mogamisi. F. K.; Tsanwani, M. Hlatshwavo, S. M: Mampa, R. M. J. Chent Research iS/ 1999. 706

9. Banerjee. A. K.: Cabrera. E. V.: Azocar. I. A. Swmh. Conmum. 2000. 30.3815

10. (a) Rickards. R. W.: Rodwell. J. L.: Schmalzl. K. J. J. Chem. Soc. Chem. Commu 1977, 849. (b) Wild. H. J. Org. Chem. 1994. 59. 2748. (c) Ihara. M. Tovota, M.: Fukumoto, K.: Kametani, I Tetrahtedon Lett. 1984. 25. 3235. (d) Ihara. M.: Toyota. M. Fukumoto. K.: Kametani. T. J. Chen. Soc. Perkin Trans. 1986. 2151. (e) Tung. M. E.: Rayle. H. L. Synth. Commun. 1994. 24. 197.

11. Baldwin. J. E.: Thomas. R. C.; Kruse. L. I.; Silberman. L. J. Org Chent $1977,42,3846$

12. Yamada. F.: Nishiyama. T.: Yamamoto. M.: Tanaka. K. Bull. Chent. Sox. Jpn. 1989. 62.3603. 